\title{
INTERNATIONAL LEGAL COOPERATION AND THE PRINCIPLE OF HARMONISATION: LESSONS FROM CROSS-BORDER INSOLVENCY
}

\author{
Emilie Ghio ${ }^{1}$ \\ Birmingham City University, United Kingdom
}

\begin{abstract}
This project assesses how harmonisation can be promoted and achieved in the EU without a completely uniform legal system in place. The project focuses on international legal cooperation as a means to promote harmonisation throughout the EU. It uses the area of crossborder insolvency law as a case study to investigate the interaction between harmonisation and international legal cooperation. This abstract presents the preliminary hypotheses and some preliminary conclusions of this project.
\end{abstract}

Keywords: International legal cooperation, harmonisation, insolvency law.

Contents: 1 Introduction. 2 Functions and agenda of harmonisation. 3 Harmonisation and international legal cooperation. 4 The challenges to the harmonisation of cross-border insolvency law in the EU: the role of international legal cooperation.

\section{INTRODUCTION}

The link between harmonisation and international legal cooperation is an intimate one. In the EU, this link is particularly visible in Article 81 of the Treaty on the Functioning of the EU (TFEU). Article 81 states that " $[\mathrm{t}]$ he Union shall develop international legal cooperation in civil matters having cross-border implications, based on the principle of mutual recognition of judgments and of decisions in extrajudicial cases. Such cooperation may include the adoption of measures for the approximation of the laws and regulations of the Member States." Article 81 gives the EU competence to promote international legal cooperation in civil matters having cross-border implications, based on the principle of mutual recognition of judgments and decisions in extrajudicial cases. The acts adopted by the EU under Article 81 TFEU may serve various purposes, including ensuring the compatibility of the private international law rules of the Member States (conflict of laws and conflict of jurisdiction). The scope of this competence is not limited by subject-matter, i.e. any aspect of conflict of law and conflict of jurisdiction may fall under the scope of Article 81.

\footnotetext{
${ }^{1}$ Lecturer in Law, Birmingham City University. Emilie.Ghio@bcu.ac.uk

${ }^{2}$ Emphasis added.
} 
As a result of the broad competence it confers upon the EU, ${ }^{3}$ Article 81 TFEU has been the legal basis of a growing number of regulations in the field of private international law and civil procedure. For example, the Regulation on Insolvency Proceedings (1346/2000) ${ }^{4}$ was the first Regulation adopted on the basis of Article 65 TEU (now Article 81 TFEU). Its recast version, (2015/848) is also one such regulation. ${ }^{5}$ The objective of the Regulation is to approximate the laws of the Member States in the area of cross-border insolvency law, which is a field falling within the scope of international legal cooperation in civil matters. ${ }^{6}$ Therefore, in the area of cross-border insolvency law, achieving harmonisation is intrinsically linked with international legal cooperation.

\section{FUNCTIONS AND AGENDA OF HARMONISATION}

The project starts by focusing on the functions and objectives of harmonisation. This theoretical analysis first looks at the context in which the harmonisation process is taking place. It focuses on the harmonisation of cross-border insolvency law in the context of furthering the integration of the EU Single Market and ensuring its smooth functioning. This section therefore determines what shape the harmonisation process must take to achieve the goals of creating an "ever closer union" 7 and being "united in diversity" in order to integrate the Single Market. ${ }^{8}$ It looks at several Treaty provisions, such as the original EU competence to build the Single Market found in Article 2 TEC; ${ }^{9}$ Article 3 TEC; ${ }^{10}$ Article 26 TFEU; ${ }^{11}$ and Article 114 TFEU. ${ }^{12}$

\footnotetext{
${ }^{3}$ Compared for example with TFEU art. 114 which is slightly more narrow as it allows the EU to enact measures for the harmonisation of national rules only if these are necessary for the establishment and functioning of the Single Market. Therefore, compared to TFEU art. 114, TFEU art. 81 does not require that a link between the EU harmonisation measures and the proper functioning of the Single Market be proven.

${ }^{4}$ Council Regulation 1346/2000/EC (29 May 2000) on insolvency proceedings, O.J. L160/1. [Hereinafter, the European Insolvency Regulation 2000].

${ }^{5}$ Regulation (EU) 2015/848 of the European Parliament and of the Council of 20 May 2015 on insolvency proceedings, OJ L 141. [Hereinafter, the European Insolvency Regulation 2015]

${ }^{6}$ European Insolvency Regulation (2015) Recital 3.

7 TEU art. 1.

${ }^{8}$ See the Europa website at https://europa.eu/european-union/about-eu/symbols/motto_en.

${ }^{9}$ TEC art. 2 reads: "The Community shall have as its task, by establishing a common market and progressively approximating the economic policies of Member States, to promote throughout the Community a harmonious development of economic activities, a continuous and balanced expansion, an increase in stability, an accelerated raising of the standard of living and closer relations between the States belonging to it."

10 TEC art. 3 reads: "For the purposes set out in Article 2, the activities of the Community shall include: ... (b) a common commercial policy; (c) an internal market characterised by the abolition, as between Member States, of obstacles to the free movement of goods, persons, services and capital; ... (h) the approximation of the laws of the Member States to the extent required for the functioning of the common market..."

${ }^{11}$ TFEU art. 26 reads: "The Union shall adopt measures with the aim of establishing or ensuring the functioning of the internal market..."

${ }^{12}$ TFEU art. 114 reads: “[...] The European Parliament and the Council shall, acting in accordance with the ordinary legislative procedure ... adopt the measures for the approximation of the provisions laid down by law ... in the Member States which have as their object the establishment and functioning of the internal market."
} 
Second, a linguistic analysis of the word "harmonisation" is undertaken, to determine whether: (1) harmonisation shuns legal diversity; and (2) harmonisation equates uniformity. The starting point is the word "approximation" which is the most commonly used word in the Treaties when speaking of furthering the integration of the Single Market. Over time, the term "approximation" has been replaced by the more generic term "harmonisation". However, the lack of consensus regarding the meaning of "harmonisation" in scholarly literature, as well as EU documents, has led to confusion regarding the true objectives of the EU in building the Single Market. In fact, this section shows that the word "harmonisation" is often used interchangeably with words such as "approximation, "convergence", "coordination" and "uniformity".

This section concludes that:

(1) Harmonisation does not mean uniformity, but rather, increased similarity;

(2) Harmonisation is an umbrella term which encompasses diverse regulatory methods such as approximation, convergence and reflexive harmonisation.

(3) Harmonisation can be achieved through different media, which include legislative measures such as regulations and directives, but also softer, more flexible media such as international legal cooperation.

\section{HARMONISATION AND international LEGAL COOPERATION}

This section links the use of harmonisation measures to achieve the overarching goal of furthering the integration of the Single Market with international legal cooperation. Starting with a constitutional analysis of Article 81 TFEU, this section then proceeds to analyse the synergy between harmonisation and international legal cooperation. As a starting point, this interaction is considered from two angles: (1) international legal cooperation as a premise to harmonisation; and (2) international legal cooperation as an alternative to harmonisation. It is anticipated that further research in this area will lead to additional associations between international legal cooperation and harmonisation.

The aim of this research is to determine whether legislative intervention is sufficient to achieve the harmonisation (defined in Section 2). It assesses how harmonisation can be promoted without a completely uniform legal system in place by looking at the role of international legal cooperation in the harmonisation process. 


\section{THE CHALLENGES TO THE HARMONISATION OF CROSS-BORDER INSOLVENCY LAW IN THE EU: The role of international legal cooperation}

The final section applies the previous theoretical discussions to the field of cross-border insolvency law. It analyses the challenges to the harmonisation process and determines what role international legal cooperation plays in promoting a more harmonised EU insolvency system. Indeed, the diversity that characterises European Union Member States' national legal systems, which is both its greatest strength and a weakness, carries through to the field of corporate insolvency law. The differences in European insolvency laws are seen as an obstacle to the proper functioning of the EU Single Market as they can hamper the effective administration of insolvency proceedings, thereby creating barriers to cross-border investment. ${ }^{13}$ As a result, harmonising the domestic insolvency regimes of the Member States has been at the top of the EU institutions' agenda over the last two decades. The latest global economic and financial crisis sped up this harmonisation frenzy as it saw an average of 200,000 firms going insolvent each year in the EU, resulting in job losses amounting to 5.1 million over three years. ${ }^{14}$

In the last five years alone, the European institutions have been very prolific in creating a comprehensive cross-border insolvency law framework, through the drafting of several legislative measures. ${ }^{15}$ A higher degree of harmonisation in insolvency law has therefore been a hot topic within the EU in recent years, not only for law-makers, but also for the judiciary who is a key institution in the insolvency system. The EU has focused on harmonising different aspects of cross-border insolvency law, such as pre-insolvency restructuring, the regulation of forum shopping and increased cooperation between courts.

The project focuses on the legal obligations imposed on EU courts in cross-border insolvency law cases. It focuses on the provisions of the European Insolvency Regulation 2015, especially Recitals 48-40; Articles 41-43; and 56-59, which bring to our attention that

\footnotetext{
${ }^{13}$ Commission Staff Working Document Executive Summary of the Impact Assessment Accompanying the document Commission Recommendation on a New Approach to Business Failure and Insolvency, SWD (2014) 61 final, at p.2 (Mar. 12 , 2014); Commission Inception Impact Assessment "Initiative on insolvency" 2-3 (2016), https://ec.europa.eu/smartregulation/roadmaps/docs/2016_just_025_insolvency_en.pdf; Directive (EU) 2019/1023 of the European Parliament and of the Council of 20 June 2019 on preventive restructuring frameworks, on discharge of debt and disqualifications, and on measures to increase the efficiency of procedures concerning restructuring, insolvency and discharge of debt, and amending Directive (EU) 2017/1132, Recital 8.

${ }^{14}$ Commission Staff Working Document Impact Assessment Accompanying the document Commission Recommendation on a New Approach to Business Failure and Insolvency, SWD (2014) 62 final, 2 (Mar. 12, 2014).

${ }^{15}$ European Commission Recommendation on a New Approach to Business Failure and Insolvency, COM(2014) 1500 final; Regulation (EU) 2015/848 of the European Parliament and of the Council of 20 May 2015 on insolvency proceedings, OJ L 141; Directive (EU) 2019/1023 of the European Parliament and of the Council of 20 June 2019 on preventive restructuring frameworks, on discharge of debt and disqualifications, and on measures to increase the efficiency of procedures concerning restructuring, insolvency and discharge of debt, and amending Directive (EU) 2017/1132.
} 
cooperation and communication across courts are fundamental mechanisms in cross-border insolvency cases. Interestingly, Recital 48 of the Regulation also request courts to take into account best practices, standards and guidelines developed by international institutions and organisations active in the area of international insolvency law. Indeed, international legal cooperation in cross-border insolvency cases has not only been a hot topic for the EU institutions, but also for international organisations such as the UN Commission on International Trade Law (UNCITRAL), ${ }^{16}$ as well as academics and practitioners who have come together to draft standards, guidelines and best practices in the area of international legal cooperation in cross-border insolvency cases. ${ }^{17}$ These initiatives represent an important step forward to align national legal systems, without amounting to complete uniformity.

Relying on the theoretical analysis provided in Section 3, this part of the project then proceeds to analyse international legal cooperation in the area of cross-border insolvency law as a premise to its harmonisation and; (2) as an alternative to the harmonisation of cross-border insolvency law.

\section{REFERENCE LIST}

Commission Inception Impact Assessment "Initiative on insolvency" (Mar. 03, 2016), https://ec.europa.eu/smart-regulation/roadmaps/docs/2016_just_025_insolvency_en.pdf.

Commission Staff Working Document Executive Summary of the Impact Assessment, SWD (2014) 61 final (Mar. 12, 2014).

Commission Staff Working Document Impact Assessment Accompanying the document Commission Recommendation on a New Approach to Business Failure and Insolvency, SWD (2014) 62 final (Mar. 12, 2014).

Council Regulation 1346/2000/EC (May 29, 2000) on insolvency proceedings, O.J. L160/1.

Directive (EU) 2019/1023 of the European Parliament and of the Council of 20 June 2019 on preventive restructuring frameworks, on discharge of debt and disqualifications, and on measures to increase the efficiency of procedures concerning restructuring, insolvency and discharge of debt, and amending Directive (EU) 2017/1132.

EU Cross-Border Insolvency Court-to-Court Cooperation Principles (Dec. 2014), https://www.universiteitleiden.nl/binaries/content/assets/rechtsgeleerdheid/fiscaal-eneconomische-vakken/cross-border.pdf.

\footnotetext{
${ }^{16}$ See e.g. UNCITRAL Model Law on Cross-Border Insolvency with Guide to Enactment and Interpretation (1997).

17 See e.g. EU Cross-Border Insolvency Court-to-Court Cooperation Principles (Dec. 2014), https://www.universiteitleiden.nl/binaries/content/assets/rechtsgeleerdheid/fiscaal-en-economische-vakken/cross-border.pdf; EU Cross-Border Insolvency Court-to-Court Guidelines $\quad$ (Dec. https://www.universiteitleiden.nl/binaries/content/assets/rechtsgeleerdheid/fiscaal-en-economische-vakken/guidelines.pdf. See also an ongoing project on Judicial Co-Operation supporting Economic Recovery in Europe (JCOERE), https://www.ucc.ie/en/jcoere/. This project aims to enhance judicial cooperation under the European Insolvency Regulation 2015 by looking at possible obstacles arising from the duty to cooperate.
} 
EU Cross-Border Insolvency Court-to-Court Guidelines (Dec. 2014), https://www.universiteitleiden.nl/binaries/content/assets/rechtsgeleerdheid/fiscaal-eneconomische-vakken/guidelines.pdf. See also an ongoing project on Judicial Co-Operation supporting Economic Recovery in Europe (JCOERE), https://www.ucc.ie/en/jcoere/.

European Commission Recommendation on a New Approach to Business Failure and Insolvency, COM (2014) 1500 final.

Regulation (EU) 2015/848 of the European Parliament and of the Council of 20 May 2015 on insolvency proceedings, OJ L 141.

Treaty on the Functioning of the European Union - TFEU

UNCITRAL Model Law on Cross-Border Insolvency with Guide to Enactment and Interpretation (1997). 